\title{
PREVENTING CHILD TRAFFICKING BY CUSTOMARY INSTITUTIONS AND LOCAL WISDOM IN ACEH PROVINCE, INDONESIA
}

\author{
Sri Walny Rahayu* \\ Teuku Ahmad Yani** \\ Azhari Yahya***
}

\begin{abstract}
This paper aims to explain the causes of child trafficking in Indonesia and the efforts made by the Customary Institutions in preventing Child Trafficking in line with local wisdom values. This paper adopts normative juridical research by using the data collected through library research on regulations for child trafficking. The approach used is the historical approach and the conceptual approach. The role of Customary Institutions in Aceh and community involvement to prevent acts of violence and child exploitation is provided in the local law. The position and function of the Aceh Customary Institutions are dominant and can be used as a model of prevention of trafficking in children. Local wisdom is traceable in society despite some of these basic values are fading due to globalization and consumerism.
\end{abstract}

Keywords: child trafficking, customary institutions, local wisdom, Aceh, Indonesia.

Associate Professor, Faculty of Law, Universitas Syiah Kuala (USK). Email: ayoe_armans@unsyiah.ac.id.

** Associate Professor, Faculty of Law, Universitas Syiah Kuala (USK). Email: teuku_yani@unsyiah.ac.id.

*** Associate Professor, Faculty of Law, Universitas Syiah Kuala (USK). Email: azhari.yahya@unsyiah.ac.id. 


\title{
MENCEGAH PEMERDAGANGAN KANAK-KANAK MELALUI INSTITUSI ADAT DAN KEPRIHATINAN TEMPATAN DI PROVINSI ACEH, INDONESIA
}

\begin{abstract}
ABSTRAK
Makalah ini bertujuan untuk menerangkan punca pemerdagangan kanakkanak dan usaha yang telah dilakukan oleh institusi adat bagi mencegah jenayah pemerdagangan kanak-kanak. Usaha ini selari dengan nilai-nilai keprihatinan tempatan yang diamalkan oleh penduduk Provinsi Aceh. Makalah ini ditulis berdasarkan penyelidikan normatif yang dilakukan melalui pembacaan bahan-bahan yang diperolehi di perpustakaan. Ianya mencakupi peraturan dan undang-undang yang melibatkan pemerdagangan kanak-kanak. Penyelidikan ini juga mengguna pakai pendekatan sejarah dan menganalisa konsep sedia ada. Peranan penting yang dimainkan oleh institusi adat dan keprihatinan dan penglibatan terus dikalangan masyarakat Aceh adalah diantara sebab mengapa pemerdagangan kanak-kanak dapat dicegah di sini. Penyelidikan mendapati ianya diperuntukkan di dalam undang-undang setempat. Kedudukan dan penggunaan institusi adat adalah diminan di Aceh dan boleh digunakan sebagai model bagi mencegah pemerdagangan kanakkanak. Sementara itu, keprihatinan masyarakat setempat masih dapat dikesan dan diamalakan di Aceh walaupun terdapat sedikit kesan pemudaran disebabkan oleh globalisasi dan kepenggunaan.
\end{abstract}

Kata kunci: pemerdagangan kanak-kanak, institusi adat, keprihatinan masyarakat setempat, Aceh, Indonesia.

\section{INTRODUCTION}

Global trade in the 21st century has definitely brought tremendous benefits to the world. Alas, with it there has also been the rise in various forms of transnational crime. In 1995, the United Nations identified 18 types of transnational crime namely money laundering, terrorism, theft of art and cultural property, theft of intellectual property, illicit arms trafficking, aircraft hijacking, sea piracy, insurance fraud, computer crime, environmental crime, trafficking in persons, trade in human body parts, illicit drug trafficking, fraudulent bankruptcy, infiltration of legal business, corruption, and bribery of public officials. ${ }^{1}$ More

${ }^{1}$ Sri Walny Rahayu, "Customary Model After the LoGA Faces Transnational Crime," in Not Ordinary law: Reflection on 10 years of the Law on the 
recently this includes more serious crimes such as human trafficking, which is made more heinous when it involves women and children.

The number of cases of violence and trafficking in children is increasing. In this regard, the actual number of cases of child trafficking that have not been revealed are more than those that have received public attention and brought to justice in Indonesia. Trafficking of women and children is a form of organized and systematic crime, with networking from big cities to remote areas. This form of crime has targeted children as the main victims because they are weak and helpless. ${ }^{2}$ Besides, as the impact of globalization is offering a practical and consumptive lifestyle, where there is a tendency of changing the public attitudes to become apathy, skeptical, individualistic, and selfish. ${ }^{3}$

Furthermore, there are eight types of transnational crimes in the Southeast Asia regulated by the ASEAN Plan of Action to Combat Transnational Crimes (ASEAN-PACTC) established in 2002. These crimes include illicit drug trafficking, human trafficking, sea piracy, arms smuggling, money laundering, terrorism, international economic crime, and cybercrime. ${ }^{4}$ Child trafficking is not just an ordinary social phenomenon, but is a serious crime for victims, their families, society, and the state. ${ }^{5}$ It is considered a violation of human rights and

Government of Aceh, ed. Sulaiman Tripa (Banda Aceh: Bandar Publishing, 2016), 80.

2 Sri Walny Rahayu, "Potential Government Institutions in Gampong, Adat and Education as Strategies for Local Resource-Based Prevention and Community Strength in the Issue of Human Trafficking in NAD," in Workshop Collaboration of the Gender Study Center Syiah Kuala University with Unicef (Banda Aceh: 2007) 8.

3 Sri Walny Rahayu, "Potential Intervention on Local Wisdom in Indigenious for Child Traffiking Prevention" in, International Proceedings Faculty of Law University" (Semarang: , 2018) 793-798.

4 Agus Subagyo, "Kesiapan Polri Menghadapi MEA 2015," accessed, Jan, 27, 2020, shorturl.at/sQR49.

5 Noer Indriati, "Pengembangan Model Perlindungan Hukum Terhadap Anak Sebagai Korban Perdagangan Dikaitkan Dengan Protokol Perdagangan Orang Pelengkap Konvensi Tindak Pidana Transnasional Terorganisasi 2000 Di Indonesia”, (Dr. Diss, Faculty of Law Padjadjaran University, 2013), 2. 
categorized as an extraordinary crime. Indonesia in particular, is targeted as a source, transit, and destination country of trafficking in men, women and children, especially for prostitution and forced labour. Based on data from the International Organization for Migration (IOM), at least $76 \%$ of women and children are lured by traffickers with an offer to work abroad as Indonesian Migrant Workers. At present, it is estimated that 6.5 million to 9.0 million migrant workers are working outside Indonesia, including 2.6 million in Malaysia and 1.8 million in the Middle East. ${ }^{6}$ In addition, the International Labor Organization (ILO) reports that 215 million children are trapped in hazardous work which puts them at risk of injury, illness or death, and vulnerable to being victims of trafficking. ${ }^{7}$

According to the data from the Indonesian Child Protection Commission (ICPC) 2018, from 2011 to 2017, there were 422 cases of child trafficking with the highest cases recorded involving sexual exploitation. It is similar to the data compiled by IOM which reported that, from 2005 to 2017 , there were 8.876 trafficking victims, 15 percent of which were children. ${ }^{8}$ Furthermore, according to ICPC, in the first three months of 2018, there were 32 cases of human trafficking and commercial sex exploitation on minors in Indonesia. From this number, eight cases involved children trafficking, 13 on child commercial sex exploitation, 9 for child prostitution, and 2 for economic exploitation.

From the records of the National Commission for Women in $2018,{ }^{9}$ there were various spectrum of violence against women

6 United States Department of State, "Trafficking in Persons Report 2010 Indonesia”, UNHCR, accessed November 22, 2019, http://www.unhcr.org/refworld/docid/4c1883ecc.html.

7 Deputy for Women's Protection, Policy on Prevention of People through Local Wisdo (Jakarta: Ministry of Women Empowerment and Child Protection, 2011), 20.

8 Chyntia Sami Bhayangkara, "Ada 32 Kasus Trafficking dan Eksploitasi Anak di Indonesia pada Awal 2018", Okezone, accessed January 27, 2020, https://news.okezone.com/read/2018/04/03/337/1881471/ada-32kasus-trafficking-dan-eksploitasi-anak-di-indonesia-pada-awal-2018.

9 Komnas Perempuan Tergerusnya Ruang Aman Perempuan Dalam Pusaran Politik Populisme, "Catatan Kekerasan Terhadap Perempuan Tahun 2017" Komnas Perempuan, accessed August, 6, 2019, 
throughout 2017; some of which included violence against girls. The violence occurred through using cyberspace media platform, such as online prostitution sites and applications under the guise of religion (for example, ayopoligami.com and nikahsiri.com), and sexual exploitation of girls in cyberspace. The threat of exploiting children is rising massively, but there is a minimal reporting and handling of the issue. ${ }^{10}$ Crimes against children can have long-term psychological, sociological, physical, and bodily effect. Victimisation of these children will leave lasting impressions on the victims and it is possible that they too will one day become perpetrators of similar crimes.

Indonesia has a set of preventive regulations for child trafficking, including law of the Republic of Indonesia No. 19 of 2016 concerning the Electronic Transaction Information (ETI law). The ETI law should be able to protect victims from crimes that use electronics devices as a medium.

The teachings of religion encourage every human being to help one another and have noble deeds. Noble behaviour is the characteristic that must be possessed by every Muslim both in relation to God and His creatures. With noble morality, human beings will be happy in their lives in the world and in the hereafter. ${ }^{11}$

The development of national identity, such as appreciation of cultural values, social solidarity values, and kinship values began to decrease. Besides, the weakness of the law-abiding culture, the ineffectiveness of national character formation, the lack of leaders' model, the rapid absorption of negative global cultures that are not in line with the national character, and the inequality of social and economic capacity are some of the issues that yet to be resolved by the Indonesian government. ${ }^{12}$

https://www.komnasperempuan.go.id/read-news-siaran-pers-catatantahunan-catahu-komnas-perempuan-2018.

10 Ibid.

11 Syarifah Md Yusof, Abu Bakar Hamed, Raziah Md Tahir, and Azizah Othman, "Usahawan Wanita Muslim Berjaya: Amalan Gaya Hidup Islam,” International Journal Of Islamic Business 3, no. 1 (2018): 01-18.

12 Sri Walny Rahayu, "Customary Justice in Aceh as a Model for Revitalizing the Establishment of Customary Legal Systems in Indonesia,", in Restorative Justice; A New Paradigm Of Criminal Law, 
There are other regulations related to child trafficking such as the Law of The Republic of Indonesia No. 21 of 2007 concerning Eradication of Criminal Acts on Trafficking in Persons, State Gazette of The Republic of Indonesia Year 2007 Number 58 (hereinafter Eradication of Criminal Acts on Trafficking in Persons), Law of The Republic of Indonesia Number 23 Year 2002 about Child Protection (Child Protection 2002) as amended by Law of The Republic of Indonesia Number 35 Year 2014 concerning Amendment to Child Protection Number 23 Year 2002 concerning Child Protection, effectively commenced on October 18, 2014 (The Modification of Law Number 35 Year 2014 concerning Child Protection; The Modification of Law Number 35 Year 2014).

Indonesia is a party to the Convention on Transnational Organized Crime 2000 and Convention Against Transnational Organized Crime 2000. Aside from that, Indonesia is also a party to the Convention Against Corruption 2003, namely Protocol to Prevent, Act and Punish Traffickers, especially for Women and Children. This protocol aims to prevent, the suppression and punishment of traffickers and supplements the Convention on Transnational Organized Crime, which was adopted by the General Assembly Resolution United Nation 55/25. This protocol came into force on December 25, 2003.

The Convention Against Transnational Organized Crime 2003 requires participant countries, including Indonesia, to take action to harmonize legislation and administrative procedures relating to the Convention by regulating trafficking of persons and child protection. The regulations must integrate and prioritize the general principles accepted by nations without abandoning the principles of original law or customary law that are still valid and relevant. According to Kamaruzzaman Bustamam-Ahmad, society in Indonesia has local wisdom (local wisdom-local genus), in the form of values that grow and develop in societies and has an impact in daily life both in the form of thought and behavioral patterns. ${ }^{13}$

ed. Ferry Fathurokman and Rena Yulia, (Jakarta: Inca Publishing, 2016) 158-185.

13 Kamaruzzaman Bustamam Ahmad, "Local Wisdom in Irfani's Epistemological Perspective, In Kearifan lokal di Laut Aceh”, ed. by M. Adli Abdullah (Banda Aceh: Syiah Kuala University Press, 2010) 4-26. 
This article wishes to concentrate on the Aceh Province and analyses how the problem of child trafficking is dealt with within the province. In Indonesia, the constitutional guarantees the basic rights of indigenous peoples (customary community) and their protection is regulated in Article $18 \mathrm{~B}$ paragraph (1) and (2) and Article 28I of the 1945 Constitution. Hence, Aceh, as a province has been endowed with special autonomous power compared to the rest of the provinces. This is evident from Law No. 44 of 1999 concerning Implementation of Privileges of Aceh Province (Speciality Act of Aceh Province Law) that defined privileges as the special authority to organize religious, customary, education and the role of religious leaders in determining regional policies. Furthermore, Law 11 of 2006 concerning the Government of Aceh was formed, to regulate various aspects of lives in Aceh Province in terms of Islamic religion, economics, politics, social, law, customs, and culture. Thus, based on these laws, Aceh is a Province adopting legal pluralism, namely national law/state law, religious law, and customary law simultaneously. The system of government, customary institutions of Aceh and the role of religious leaders in Aceh are the central figures in the axis of society. This approach is a system that operates under the principles and concepts of the development of Indonesian national law. ${ }^{14}$

The position and authority of the Customary Institutions of Aceh lies within Article 98 of Law Number 11 of 2006 on Aceh Government (UUPA). This provision is supplemented by the implementation of Article 98 of UUPA, namely Qanun Number 9 of 2008 concerning the Establishment of Customary Life and Qanun Number 10 of 2008 concerning Customary Institutions. In Qanun Number 9 of 2008, it explicitly states that the duties and authorities of Customary Institutions in Aceh do not only function as traditional institutions, but also have the authority to try and resolve customary disputes in court (Customary Court). The Qanun was substantiated by the Governor Regulation Number 60 of 2013 concerning the Implementation of Settling Customary Disputes. Besides, other important rules regarding the authority of customary institutions can be found in Qanun Number

14 Sri Walny Rahayu, "Lembaga Penyelesaian Sengketa Adat Laut, Panglima Laot di Aceh Sebagai Bentuk Pengembangan Alternatif Penyelesaian Sengketa dalam Sistem Hukum Indonesia," Padjadjaran Journal of Law- PJIH-Bandung (2014): 448-467. 
4 of 2003 concerning the Government of Mukim (a customary region within a sub-district) and Qanun Number 5 of 2003 concerning Government of Gampong (village).

In relation to the discussion on child trafficking within the province, various crimes against children still occur although child protection, especially of girls in Aceh, has been covered in Qanun No. 11 of 2008 concerning Child Protection and Qanun Number 6 of 2009 concerning the Protection and Women Empowerment. It has been discovered that, crime against children is frequently committed by the person having closest relationship to the victim. In a case that occurred in the West Aceh District, for example, the sexual exploitation of minors was done by the victim's parents. The public prosecutor demanded each defendant to be punished with 50 times of caning, or fined 500 grams of pure gold, or 50 months in prison. The panel judges of the Syariah Court (Islamic Court) of West Aceh Regency decided a more severe decision than the prosecutor's indictment, namely a sentence of 75 months (6.3 years) imprisonment for each defendant. ${ }^{15}$

The problems described above are very serious. Even though Indonesia has some regulations regarding the Eradication of Criminal Acts on Trafficking in Persons Law and Child Protection Law, child trafficking continues to occur. Therefore, customary institutions in Indonesia are expected to understand the mode of trafficking in persons, as well as other forms of crime related to child protection. The role of Customary institutions is to maintain public order in the village, optimize the role of religious leaders and the local wisdom of Indonesian people in order to protect the society against various crimes, including child trafficking. Based on the facts stated above, the purpose of this article is to explain the position of customary institutions within Gampong as customary justice in positive law, efforts made by the customary institutions within the Gampong to prevent child trafficking in Aceh and the impact of information technology and globalization in child trafficking in Indonesia.

15 "Pasutri divonis 6,3 tahun penjara," Aceh Tribunnews, accessed January 27, 2020, https://aceh.tribunnews.com/2018/08/04/pasutri-divonis-63tahun-penjara. 


\section{RESEARCH METHODS}

This article is based on a study uses a type of normative juridical research, a method in which the main data comes from secondary data or the primary legal material of legislation relating to the study. Secondary legal material referred to consists of books, journals, articles, while tertiary legal materials originate from websites and dictionaries. Employing the historical approach and the conceptual approach, the research utilises an analytical approach to the sources, in which the data is analyzed based on a qualitative juridical approach, then presented in the form of a description.

\section{RESULTS OF THE STUDY}

\section{The causes of child trafficking in Indonesia}

All countries in the world have experienced the problem of trafficking in persons with varying levels of seriousness. In this regard, there are the destination, transit, and source countries for trafficking in persons, as experienced by Indonesia. ${ }^{16}$ Trafficking in persons is a new form of slavery in the modern era. It was also noted by John Wagley ${ }^{17}$ that adult trafficking is synonymous with slavery in the modern era. ${ }^{18}$ Women and children are the target of trafficking in persons to be sexually exploited or used for forced labor, in their country and abroad. The phenomenon of domestic trafficking in persons is also increasingly diverse in form and mode. Prostitution, both in the formal area and hidden prostitution is increasingly widespread, both in big cities and in rural areas. IOM database (March 2005-2011) reported that there were 749 girls and 150 boys being child victims of prostitution. ${ }^{19}$ Additionally, in urban areas, beggars and street children are exploited for economic purposes. Ironically, it was found that the perpetrators in such a case were adults, and sadly, their respective parents.

16 Kevin Bales, Disposable People: New Slavery in the Global Economy (Berkeley: University of California Press, 1999), 34.

17 Wagley, R, Human Trafficking, An Overview Washington, DC: 2002, (Wasington, DC: Center for Advanced Defense Studies, 2007), 2.

18 Ibid.

19 International Organization for Migration, Counter-Trafficking Database, (March 2004-December 2010). 
The mode of entanglement of victims of child trafficking targeting young women through cyber sites is also very upsetting . Actors communicate with victims through various social networking applications. Furthermore, the perpetrators of the crime commit deception, subsequently leading to sexual exploitation. For example, Facebook is one of the social media platforms to trick victims. Victims were lured by their friends with whom they became acquainted through Facebook. ${ }^{20}$ Another mode is that more adult women and adolescents are victims of trafficking by becoming drug couriers because they are promised a number of prizes in the form of money, dating or marriage opportunities by the perpetrators.

It is submitted that communities need to be aware of the various modes that may trigger these crimes. Peer invitations in the community of children or other people outside the child's family, should alert the parents. In addition, transactions through electronic or social media need to be observed closely. The use of advanced technology has made it possible for commercial sexual exploitation and even children have been involved in these prostitution networks. Traffickers use private spaces such as hotels, apartments, and private residences for prostitution. This also made it more difficult for the apparatus to detect the occurrence of crimes against children. Hence, there is an urgent need for the community to play its role in preventing these crimes from happening within their communities. This can be done in collaboration with the leaders of the community as well as the ulama and traditional institutions. The role of the community in keeping a watch over these children may help prevent or reveal cases of child trafficking. This is called participatory prevention of early detection of Gampong (village). ${ }^{21}$

Poverty can also be a factor leading to child trafficking. Some poor children are married off quickly to reduce the responsibilities of

20 Sri Walny Rahayu, "Indigenous Institutions and the Local Wisdom Values in Indonesia as one of the Prevention Strategies of the Child Trafficking in the AEC, Proceeding International Conference (SBC-MEA)".

21 Noer Indriati, "Pengembangan Model Perlindungan Hukum Terhadap Anak Sebagai Korban Perdagangan Dikaitkan Dengan Protokol Perdagangan Orang Pelengkap Konvensi Tindak Pidana Transnasional Terorganisasi 2000 Di Indonesia," Fakultas Hukum Jenderal Soedirman (2017): 7. 
parents economically. ${ }^{22}$ This is based on the assumption that Indonesia is a poor country, so that it becomes a sender even though the assumption of poverty does not necessarily guarantee the reason for trafficking, because Indonesia is also a destination for trafficking. In 2010 , it was reported that poverty is a driving factor for people to migrate and look for alternative income outside their villages, regions, and countries or residence. Although the poverty rate has declined in 2010 from $14.2 \%$ to $13.3 \%$, it has not significantly reduced the number of victims of trafficking in persons in Indonesia. ${ }^{23}$ The weakness of individuals and families in preventing trafficking causes people to easily become victims. ${ }^{24}$ Poverty, low levels of education, the desire to improve income, and changes in lifestyle also weaken individual power to deter such incidences from occuring.

Other than poverty, the absence of a birth certificate is also a contributing factor to this heinous crime. According to the data from UNICEF in 2007, around 37 per cent of toddlers in Indonesia do not have birth certificates and low birth registration especially in the village/gampong community. The absence of a certificate causes forgery of age when arranging documents for migratory departure equipment. In 2014, based on the results of a study in Aceh Besar, it was found that 55 per cent of children did not have birth certificates, while those who had birth certificates consists of 45 per cent of the population. $^{25}$

It is also submitted that the lack of government attention in improving the education system where the curriculum is burdensome,

22 Sri Walny Rahayu, "Potential Intervention on Local Wisdom in Indigenious for Child Traffiking prevention," Jurnal Abulyatama (2016): $7-8$.

23 Linda A, Kebijakan Pencegahan Perdagangan Orang Melalui Pendekatan Kearifan Lokal (Jakarta: Kementerian Pemberdayaan Perempuan dan Perlindungan Anak Republik Indonesia, 2011), 4.

24 Noer Indriati, "Pengembangan Model Perlindungan Hukum Terhadap Anak Sebagai Korban Perdagangan Dikaitkan Dengan Protokol Perdagangan Orang Pelengkap Konvensi Tindak Pidana Transnasional Terorganisasi 2000 Di Indonesia," Fakultas Hukum Jenderal Soedirman (2017): 5.

25 Unicef and Bapeda Aceh Besar, Assessment Akte Kelahiran Di Aceh Besar (Aceh: 2013) 5. 
confuses current and prospective students. This complex situation influences their tendency to choose to work in the informal sector or get married early. These are easy options that does not to require administrative prerequisites and is accompanied by the lure of material aspects that is utilized by brokers.

Apart from this, Indonesia is a multicultural country, where most of the cultural values potentially weakens the position of women and children. For example, because poorer people get married sooner it is better to reduce the responsibilities of parents economically. In the article written by Grace Agonda Akolokwu and Barakat Adebisi Raji, discriminatory customary practices against the protection of gender rights still thrive in many developing states including Indonesia despite various domestic and international legal regimes to prevent them. ${ }^{26}$ The patriarchal system that is usually promoted by various customary laws emphasising the father's line has worsened the fate of the women who are conditioned by the society to play a second fiddle role to the male. ${ }^{27}$ With an assured traditional role in the kitchen, which does not require any kind of education, the sentiments provoking the idea that a girl does not need to go to school to become a good wife and mother as long as she has the cooking, cleaning and sewing skills still persist in the 21 st century. ${ }^{28}$

Another more nefarious reason is where the law enforcement is under the influence of traffickers. In 2018, Komnas Perempuan, stated that trafficking actors who have the authority and power politically and spiritually tend to be underreported and minimally documented. For example, religious leaders and spiritual figures, pesantren owners, members of the House of Representatives, military officials, and

26 Grace Agonda Akolokwu and Barakat Adebisi Raji, "Discriminatory Customary Practices Against Women's Rights: An Account Of Intervention Strategies By Southern African Developing States," IIUM Law Journal 27, no. 1 (2019): 89 - 120.

27 Mikateko Joyce Maluleke, "Culture, Tradition, Custom, Law and Gender Equality," Potchefstroom Electronic Law Journal/Potchefstroomse Elektroniese Regsblad 15, no. 1 (2012): 33-48.

28 Grace Agonda Akolokwu and Barakat Adebisi Raji, "Discriminatory Customary Practices Against Women's Rights An Account Ofintervention Strategies Bysouthern African Developing States.” IIUM Law Journal. 27, no. 1 (2019): 91-92. 
corporate actors may very well fall prey to being controlled by these traffickers.

\section{Regulations of Child Trafficking in Indonesia}

International treaties, whose enforcement is also applicable under domestic law, have been promulgated in order to protect the legal interests of citizens (individuals). Some examples are the United Nations Convention Against Corruption 2003 and the United Nations Convention Against Transnational Organized Crime 2000, which are often referred to as standard or harmonized-setting treaties. They do not create norms but only requires the State to create these norms in its national law. ${ }^{29}$

The UN Convention on (Transnational Organized Crime 2000 Convention Against Transnational Organized Crime 2000, is a United Nations Convention against Acts) transnational organized crime. The consequence of the ratification of the Convention is that States commit to take a series of actions against transnational organized crime, including criminalisation in their own country.

Each participating country, including Indonesia, is obliged to take necessary actions or steps, such as harmonising laws and administrative procedures relating to the convention without ignoring the principles of territorial sovereignty, territorial integrity, and nonintervention. The obligation that must be carried out by Indonesia as a participant of the convention, and a reflection of the participation of Indonesia is evident from the establishment of the Eradication of Criminal Acts on Trafficking in Persons.

The UN Protocol on Trafficking in Persons defines the trafficking in persons. Article 3 of the UN Protocol as organized crimes states the following:

Record, transportation, shipping, transit or acceptance of people with threats or use of power or other forms of coercion, kidnapping, fraud, abuse of power or position vulnerable, or giving or receiving

29 Damos Dumoli Agusman, Hukum Perjanjian Internasional - Kajian Teori dan Praktik Indonesia (Bandung: Refika Aditama, 2010), 99. 
payments or profits to get permission from someone who has control or someone else, for the purpose of exploitation.

Further, article 4 of the United Nations Trafficking Protocol states the purpose of the Protocol. It states:

This protocol has the scope of entry into transnational criminal trafficking and involves transnational criminal groups, as well as protection of victims of crime. The protocol also regulates the obligation of States parties to carry out the contents of the protocol, namely by issuing legislation and taking steps to provide protection.

In reference to Article 3 of the UN Protocol on Trafficking in Persons, the Eradication of Criminal Acts on Trafficking in Persons Act in Indonesia, "Trafficking in Persons" is defined as regulated in Article 1, as follows:

Human trafficking is the act of recruiting, transporting, sending, transferring or receiving with someone the threat of violence, the use of violence, kidnapping, confinement, forgery, fraud, the use of power or vulnerable positions, debt bondage or providing payments or benefits, so that the person who has control over another person obtains approval, both within the State, for the purpose exploitation or causing people to be exploited.

The above provisions are general provisions that seek to protect all victims of human trafficking. There is also additional protection that is afforded to children. Such protection of children is an effort to create a condition so that every child can obtain his rights. ${ }^{30}$ The definition of child protection is regulated by Article 1 Paragraph 2 of the Child Protection Act, as follows:

All activities to guarantee and protect children and their rights so that they can live, grow, develop, and participate optimally in accordance with human dignity and dignity, and receive protection from violence and discrimination" Next Article 76 F said Child Protection Law " Everyone is prohibited from placing, letting, doing, ordering, or participating in kidnapping, selling, and / or trafficking of children.

30 Arif Gosita, Masalah Korban Kejahatan (kumpulan karangan) (Jakarta: Bhuana Ilmu Populer Kelompok Gramedia, 2002), 246. 
The definition of trafficking in women and children in the Presidential Decree of Republic of Indonesia Number 88 of 2002 concerning the National Action Plan (NAP) for the Elimination of Trafficking in Women and Children provides:

All acts of traffickers that contain one or more recruitment actions, transport regional and inter-state, transfer, departure, temporary reception and shelter or in women and children - by means of threats, use of physical verbal violence, kidnapping, fraud, deception, exploiting the position of vulnerability (for example, if someone has no other choice), isolated, drug dependence, debt trap, etc.), providing or receiving payments or benefits, where women and children are used for the purpose of sexual prostitution and exploitation (including pi), legal and illegal migrant workers, adoption of children, work, bridal orders, housemaids, begging, porn industry rafi, the circulation of illegal drugs, and the sale of organs and other forms of exploitation

The efforts of the international community or countries to prevent and eradicate transnational crimes can be carried out in cooperation with Aceh Customary Institution. Important legal developments at the international level have resulted from a multilateral international agreement known as the Convention on the Rights of the Child 1990 with the power to bind countries both juridically and politically. The Convention on the Rights of the Child contains four fundamental general principles that must be implemented by every country in the context of protecting children's rights, namely the principle of non-discrimination, the best interests of children, the right to live, survive and develop, and the right to participate. There is a need to raise community awareness on the right of children to anticipate such trafficking of children and the need to prevent them from happening.

\section{Aceh Customary Institutions and Local Wisdom Values in Preventing Children Trafficking}

The juridical foundation, constitutional and idealism principles together with the concept of national legal development are explicitly stated in the preamble of the 1945 Constitution. The fourth paragraph contains the main points of thought, which are the elaboration of values 
contained in Pancasila, reflecting the characteristics and patterns of indigenous peoples and customary laws in Indonesia. The preamble is in line with the principles of regional sovereignty, territorial integrity, and non-intervention. ${ }^{31}$ Every country has a strong foundation to protect its people ${ }^{32}$ according to their local philosophy and wisdom.

Indonesia has local wisdom which is passed down from generation to generation, a hereditary ancestral wealth in the form of values that grow and develop in society. These values must be maintained properly in facing globalisation which offers a more pragmatic and consumptive lifestyle. ${ }^{33}$ "Local wisdom" is defined as a wealth of local culture that contains a policy of life that accommodates wisdom. Local wisdom does not only apply locally to certain cultures or ethnicities but can be said to be cross-cultural or cross-ethnic, forming a national cultural value. For example, almost in every local culture in Indonesia recognises local wisdom that teaches cooperation, tolerance, work ethic, and so on. In general, ethics and moral values contained in local wisdom are taught and passed down from generation to generation through oral literature, among others in the form of proverbs, folklore, hadih maja, ${ }^{34}$ and manuscripts.

31 Padmo Wahjono, "Pembangunan Hukum di Indonesia”, 153-155, Jakarta: Ind-Hill Co, 1989, in Marine Bussiness Dispute Resulotion Associated with The Indigenous Community of Panglima Laot as Development Efforts of Aternative Dispute Resolution in the Indonesian Legal System, ed. Sri Wahyuni (Bandung: Faculty of law Padjadjaran University, 2014): 63.

32 Ho Peng Kwang, Johan Shamsuddin Sabaruddin and Saroja Dhanapal, "An Overview Of The Rule Of Law Values Within Malaysia's AntiTerror Law: A Legal Perspectives From India And The United Kingdom," UUMJLS 8, (2017): 57-85.

33 Sri Walny Rahayu, "Marine Bussiness Dispute Resulotion Associated with The Indigenous Community of Panglima Laot as Development Efforts of Aternative Dispute Resolution in the Indonesian Legal System," (PhD diss., Universitas Syiah Kuala, 2013). 79.

34 This means traditional oral literature (traditional sayings) which are thought to have existed since ancient times and used for various reasons. It is a particularly well-known form of literature that is practiced in Aceh. For further reading see Erwina Gusti and Siti Aisah Ginting, "The Fading of Hadih Maja in the Vernacular Language Among Acehnese Teenagers in Banda Aceh", English Education International Conference Vol. 1, No. 
It is submitted that customary institutions can play a role in disseminating values through local wisdom and providing awareness to the community members so that they do not easily accept potential traffickers' invitation to work overseas especially through unofficial channels, which may lead to being trapped in the practice of child trafficking. Traditional institutions and figures should understand various modes and criminal acts of trafficking in persons and other forms of crime related to child trafficking, which are contrary to the values of local wisdom. In Aceh, the customs and teachings of Islam are portrayed as Hukôm ngon Adat lagee Zat ngon Sifeut (law with custom is inseparable like substance with nature). Law (hukom) as a substance, therefore it is difficult to change. Law is a substance that is derived from Islamic law, while custom patterns of behaviour are essentially unchanged. The model for preventing child trafficking by customary institutions may be as follows:

\section{a. Potential of Customary Institutions and Local Wisdom Values in Aceh Province}

Religion and Islamic culture have an important role and greatly affect the daily lives of the Acehnese people, which is why Aceh is known as Serambi Mekah (Seuramo Mecca). The name was given because those who want to perform the pilgrimage to Mecca depart from the Aceh region. ${ }^{35}$ Acehnese people have chosen to make Islam as a guide in all aspects of their lives and is an inseparable part of life. Hence, Islamic teachings gave birth to the value of local wisdom and Acehnese culture, which is reflected in their traditional life and traditional institutions. ${ }^{36}$ Furthermore, Abd Ghani Ahmad mentions that the influence of the

2

(2016),

available

at

http://www.jurnal.unsyiah.ac.id/EEIC/article/view/16283/0.

35 Hasjmy, A, Sejarah Masuk dan Berkembangnya Islam di Indonesia, (Bandung: Al-Ma'arif, 1981), 193-196.

36 Sri Walny Rahayu, "Alternative Dispute Resolution Through Customary Tribunal In The Context Of Legal Pluralism In Aceh,", International Journal of Civil Engineering and Technology (IJCIET) 9, no. 1, (2018) : 472-483. 
Islamic religion can be found within customary laws enforced in Aceh. ${ }^{37}$

Local wisdom that is widely recognised in customary law, continues to thrive and develop within indigenous communities, making it an inseparable part of the dynamics of indigenous peoples themselves. Generally, the local wisdom absorbed in customary law and customary institutions in Aceh is maintained through two ways, namely community members' behavioural practices and oral maintenance. Oral maintenance by implanting custom expressions hadih maja, ${ }^{38}$ is maintained until now for generations.

Traditional institutions developed in the life of the Acehnese people have long played an important role in fostering cultural values, customary norms, and rules for realizing security, order, peace, harmony, and prosperity for the people of Aceh in accordance with Islamic values. The role of customary institutions needs to be increased not only to function as a means to preserve adat and customs as a manifestation of the implementation of Aceh's specificity and privilege in the field of customs, but also as an institution that can intervene in various forms of prevention from trafficking crimes. ${ }^{39}$

Law on Aceh Government No. 11 of 2006 Chapter XIII Article 98 paragraph (1) - paragraph (3) opens the space for potentially active institutions as the initial guard in the prevention of various forms of crime in the village community. In the 98 Law on Aceh Government, customary institutions function and serve as a vehicle for community participation in the administration of the Aceh provincial and district/municipality government in the fields of security, peace, harmony and public order. Other things are also regulated in resolving customary social problems through customary institutions. The primary customary institution in Aceh is the Aceh Adat Assembly. According to Nico Ngani, the village head called Keuchik also serves

37 Abd Ghani Ahmad and Nuarrual Hilal Md Dahlan, "Mengandung Anak Tak Sah Taraf: Kajian Kes Di Daerah Kubang Pasu, Kedah," UUMJLS 8, no. 1 (2017): 17-55.

38 Aboe Bakar, Kamus Aceh Indonesia (Jakarta: Balai Pustaka, 2001), 273.

39 Sri Walny Rahayu, "Potential Intervention on Local Wisdom in Indigenious for Child Traffiking Prevention," in International Proceedings Faculty of Law University 17 Agustus 1945 (Indonesia : University August 17, 1945, 2018) 793-798. 
as a justice representative for the village, who is allowed to react to offenses that do not fall within the competence government. ${ }^{40}$

It is worth mentioning here that Aceh has passed Qanun Number 11 of 2008 concerning child protection, which regulates the issue of violence, trafficking and exploitation of children. customary institutions in Aceh can play a role in prevention efforts of trafficking in children through rules that are further regulated in the Qanun of Child Protection in Articles 28, 29, 31 and 33.

Article no. 28 of Qanun for Child Protection, issued in 2008, mentioned that legal subjects in the form of bodies and or adults are prohibited from carrying out acts of violence against children in the form of physical, psychological and sexual violence. Furthermore, what is meant by child trafficking is regulated in article 29 of the Qanun for Child Protection 2008, in which the agency and/or persons are prohibited from performing child trafficking. Bodies and/or people are prohibited from adopting children through forced withdrawal, fraud, and kidnapping from the power of their parents/guardians or families that eliminate the child's basic rights. The Qanun for Child Protection requires the provincial/district/city government to prevent violence and trafficking in children as referred to in article 28 and 29 of the Qanun for Child Protection 2008.

The forms of exploitation of children are regulated by article 30 (1) and (2) 2008 Child Protection Qanun, namely, sexual exploitation, forced labour, involvement in political activities, slavery, retrieval/sale of children's organs for personal or group benefits. Anyone is prohibited from exploiting children by depriving them from independence, as well as the right to life and develop their children properly and fairly.

Victim's rights are protected and mentioned in article 31 of the 2008 Child Protection Qanun that every child who experiences violence, trafficking and exploitation has the right to protection; informed by the public to the authorities, has access to integrated service institutions to the extent of obtaining rehabilitation assistance

40 Nico Ngani, Perkembangan Hukum Adat Indonesia (Jakarta: PT. Buku Seru. 2012), 12. 
and they must be handled in secret both from individuals, groups or institutions both government and non-government.

In the event of violence, trafficking and exploitation of children, each victim has the right to receive protection and assistance, psychologically and they can also obtain guarantees for his rights relating to his status as a child, family member or community member provided in article 32 of Qanun on Children Protection 2008. This law also regulates the obligation of the Aceh government and the district/city government to be responsible for implementing efforts to prevent violence, trafficking and exploitation of children. As stated in Article 33 paragraph (1) - paragraph (4), this can be carried out by:

(a) collecting data and information about children's victims of violence, trafficking and exploitation under the provisions of the legislation;

(b) educating values of anti-violence, trafficking, and exploitation of children;

(c) Disseminating legislation relating to the protection of children victims of violence, trafficking and exploitation; and

(d) conducting monitoring and evaluation of the protection of child victims of violence, trafficking, and exploitation.

In anticipating criminal acts of violence, trade, and exploitation, the government of Aceh and the district/city government are obliged to provide services for victims through:

(a) establishing and facilitating the implementation of integrated service institutions for victims involving community elements; and

(b) encouraging public awareness of the importance of protecting victims. (Article 33 paragraph (2) Qanun for Child Protection of 2008)

The Aceh and the district/city government are obliged to provide services for victims by first establishing and facilitating the implementation of integrated service institutions for victims involving community elements, and second, by encouraging public awareness of 
the importance of protecting victims. (Article 33 paragraph (2) Qanun for Child Protection of 2008)

In carrying out their obligations, the Aceh government and district/city governments must pay attention to the rights and obligations of parents, guardians or other people who are legally responsible for victims as stated in Article 33 paragraph (3). It is also a duty upon every member of the community to report all actions that lead to acts of violence, trafficking, and exploitation of a child as mentioned Article 33 paragraph (4) Qanun for Child Protection of 2008).

The role of Customary Institutions in Aceh and community involvement to prevent acts of violence and child exploitation has been contained in the provisions of local law. Thus, the actual role and contribution of the customary institutions should be sought optimally so that the position and role can be felt directly by the community. Adat institutions in Aceh can incorporate elements of tradition and values of local wisdom in Reusam Gampong involving traditional leaders and ulama in the prevention of violence and exploitation of children. It is therefore clear that the role of customary institutions is not merely a symbol, but an effective village campaign that can serve as an early prevention model. The source of reusam comes from the values of local wisdom which are still maintained and developed according to the needs of the times.

\section{b. Local Wisdom in Aceh}

In Aceh, advice given by seniors or religious scholars through imagery or hadih maja is considered as local wisdom. In philosophy literature, those who can issue wisdom to others are called wise men. Charles Taylor states, "the practically wise man (phronimos) the knowledge of how to behave in a particular situation which can never be equated with knowledge of general truth". ${ }^{41}$

Social status, religion and the experience or thoughts of the ulema are very influential when issuing wise pronouncements. The

41 Taylor and Charles, Sources of Self: The Making of the Modern Identity, (Cambridge: Harvard University Press, 1989), 175. 
thought of a wise man is viewed as advice or mahfudhat (aphorisms). Thus, wisdom is produced by wise men at the local level, or those who come from the heads of adat institutions, religious advisors, community leaders, or local scientists often known as poets. Local values which later become local wisdom can be interpreted as a reproduction of the thoughts of the authorities, which in turn are able to influence the local community. ${ }^{42}$ In the context of Aceh, the existence of hadith as a representation of local knowledge is local wisdom. The value of local wisdom is an afterthought to be gentle to children, with songs to lull children, many of which are sung by the Acehnese in the past.

The value of local wisdom that protects children from child trafficking, ${ }^{43}$ namely, "...... ngoen haba mangat, geu tanyoe meukeumat bak saboh period, menyoe geu tanyoe na ta remember tentei seulamat tub deception...”, which means, “...don't be fooled by sweet promises because someday we will be in trouble. But if we can be wary of course we will be safe from deception". ${ }^{4}$

\section{CONCLUSION}

The position and function of the Aceh Customary Institutions are dominant based on positive law, by involving local scholars and villagers, thus it can be used as a model for the prevention of trafficking in children in Indonesia. Local wisdom that is widely recognised as customary law that lives and develops in indigenous communities,

42 Kamaruzzaman Bustamam-Ahmad, "Local Wisdom in Irfani's Epistemological Perspective, In Kearifan lokal di Laut Aceh," Jurnal Biologi Edukasi 7, no. 1 (2015): 47-55.

43 Sri Walny Rahayu, "Potential Intervention on Local Wisdom in Indigenious for Child Traffiking Prevention," LPPM University of Abulyatama (2016): 20-13.

44 Sri Walny Rahayu, "Potential Government Institutions in Gampong, Adat and Education as Strategies for Local Resource-Based Prevention and Community Strength in the Issue of Human Trafficking in Nanggroe Aceh Darussalam", in Workshop Collaboration Gender Study Center Syiah Kuala University with Unicef (Banda Aceh : Syiah Kuala University, 2007) 15. 
making it an inseparable part of the dynamics of the indigenous peoples themselves. The role of customary institutions in Aceh and community involvement to prevent acts of violence and child exploitation has been contained in the provisions of local law. The customary institution is the forerunner as an agent of renewal and change within the society by empowering the values of local wisdom and having the authority to maintain order at the village level. The provincial or city-level regulatory agencies should have an ontological, epistemological, and axiological understanding of the Qanun arrangement or the Regional Regulation. Such understanding can allow the incorporation of the values of the local wisdom in positive law. This would allow the growth and evolution of local values in society as a meta-norm. This could ensure prevention of crime and contribute to the effectiveness of law enforcement in cases chil trafficking not only in Aceh but also in Indonesia as a whole. 